\title{
Frederick Coates: First World War 'facial architect'
}

Article

Accepted Version

Gehrhardt, M. and Steele, S. (2017) Frederick Coates: First World War 'facial architect'. Journal of War and Culture Studies, 10 (1). pp. 7-24. ISSN 1752-6280 doi: https://doi.org/10.1080/17526272.2016.1238564 Available at https://centaur.reading.ac.uk/66446/

It is advisable to refer to the publisher's version if you intend to cite from the work. See Guidance on citing.

To link to this article DOI: http://dx.doi.org/10.1080/17526272.2016.1238564

Publisher: Taylor and Francis

All outputs in CentAUR are protected by Intellectual Property Rights law, including copyright law. Copyright and IPR is retained by the creators or other copyright holders. Terms and conditions for use of this material are defined in the End User Agreement.

\section{www.reading.ac.uk/centaur}

\section{CentAUR}

Central Archive at the University of Reading

Reading's research outputs online 


\begin{abstract}
:
The role of artists in the First World War is often understood only in terms of their artistic response to the conflict in paint, music, sculpture or photography. In fact, artists' contributions were also engaged at an applied level, in the areas of propaganda, camouflage, map-making and many other trades. Beyond this, a small number actively participated as artists in repairing the damage caused by the conflict. Frederick Coates, a British-born sculptor who emigrated to Canada in 1913, was one of these artists. After enlisting with the Canadian Expeditionary Force, he worked for three years alongside surgeons and other artists in England to try and help give new features to facially injured combatants.

Drawing upon unpublished photographs and Coates's own scrapbooks, this article investigates the young artist's experience of the war and his contribution to the reconstruction of broken faces. Through a close examination of this 'facial architect', as Coates was called, this article gives a fresh insight into the work performed in maxillofacial hospitals during the First World War, especially with regard to Allied practitioners and patients. It also underlines the newly developed concept of, and importance of, cross-national, multi-disciplinary collaboration in plastic surgery wards, and the effects working in this environment had on the staff.
\end{abstract}

\title{
Key words:
}

\author{
Disfigurement \\ Epitheses \\ First World War \\ Sculpture \\ Maxillofacial hospital
}




\section{Introduction}

The role played by artists during the First World War is often understood in terms of the artistic reflections of, or portrayal of, the conflict, either in official war artist capacities or work that is incidental and personal to their service. Certainly many artists, such as the painter C.W.R. Nevinson, were anxious to get to the front lines. As Nevinson writes:

All artists should go to the front to strengthen their art by a worship of physical and moral courage and a fearless desire of adventure, risk and daring and to free themselves from the canker of professors, archaeologists, cicerones, antiquaries and beauty worshipers (quoted in Walsh, 2002: 98).

But there is another story to be told in artists' contributions to the unfolding of scientific and medical developments throughout the war. Frederick Coates, like the better-known Henry Tonks, was one of many artists employed in the restoration of the facially disfigured combatants and nurses. If the war-related work of Tonks has received growing attention since the late twentieth century (Biernoff, 2010; Chambers, 2009; Helmers, 2010), the part played by other artists in support of facially injured soldiers has rarely been studied. This article examines the life and work of the 'facial architect' (Toronto Star Weekly, August 1934: n.p.), as Coates came to be known, in acknowledgement of the years he spent constructing prostheses for combatants who had been disfigured on the battlefields, and importantly, for his work alongside surgeons in the operating theatre, advising them on the aesthetics of facial reconstruction.

The number and frequency of facial wounds during the war $-11 \%$ to $14 \%$ of all wounds affected the area of the face according to French historian Sophie Delaporte (1996) - has attracted the interest of scholars in recent years, their work examining the techniques and lives of pioneering surgeons and the workings of specialized hospitals, but also the presence of artists and the ambiguity between 'portraiture and medical record' (Chambers 2009: 579), especially with regard to British artists. This article examines the role played by Frederick Coates in the plastic surgery and prosthetic studios of the hospitals at Westcliffe, Orpington, and Sidcup, and situates his work within the genre of medical portraiture alongside that of Tonks, Francis Derwent Wood and Anna Coleman Ladd. This article sets out to expand the study of this field through drawing a more inclusive picture of the workings of the facial reconstruction teams, which until now has focused primarily on The Queen's Hospital, Sidcup and the partnership of Harold Gillies and Tonks (Biernoff, 2010; Chambers, 2009; Bamji, 2003). Based on primary research in the Frederick Coates fonds at the University of Toronto, this article outlines the story of the remarkable work done by one of the numerous Allied health and artist practitioners from many nations who made significant contributions to the development of maxillofacial surgery in a number of hospitals during the war (Hussey, 2014: 598).

What differentiates Coates from Wood or Ladd in this field is his role within the surgical suite. While pictorial evidence shows the artist in his studio constructing facial prosthetics for facially disfigured and amputee soldiers (Coates fonds, B75-0015/018P (38), (11), (31), (05)), his active participation advising surgeons on aesthetics of reconstruction, stands out. Beyond the intimate connection between artistic and surgical practice in the context of First World War reconstructive surgery, this article provides an insight into the workings of three of the 'sister' hospitals: the Queen's Hospital, the largest purpose-built maxillofacial hospital in Great Britain, the Ontario Hospital (No. 16 General Canadian Hospital) at Orpington, Kent, and the Westcliffe Eye and Ear Hospital at Folkestone. While the study focuses on Coates, it recognises that he did 
not work in isolation, and although the main sources (photographs, sketchbooks, field notebooks and ephemera) used here come from the Coates fonds, his practice will be contextualised within the broader network of multi-national artists and medical experts whose fruitful collaboration led to innovative surgical and prosthetic solutions in the service of the rehabilitation of the facially disfigured.

\section{From sculptor to 'facial architect'}

Frederick Coates was born in Nottingham in 1890 and was educated at the Nottingham School of Art where he studied drawing and architectural history. After a period of study in Paris, he returned to England in 1911 to attend the Royal College of Art, where he flourished, remarkably achieving the equivalent of three years' instruction within a single year and receiving an award for the design of a bronze pedestal in 1913 (Coates fonds, B75-0015/018P (43)). Evidence of Coates's early talent and exceptional understanding of anatomy can be seen in photographs of his studio work, and the extensive collection of charcoal and pencil sketches held in the Coates fonds. Equally, his sculpted models from throughout his career show a systematic and architectural approach to human anatomy, especially of the male nude, that displays an intimate and passionate knowledge of the human body.

Despite his success in London in 1913, Coates emigrated to Toronto, Canada's largest city, where he worked as an architectural model builder. Soon after Coates settled in Toronto, he was enmeshed in the local community of sculptors, actors, theatre directors, singers and artists, and significantly, in the context of this study, the artist Walter R. Duff (Makovsky, 1997:15-16). These early associations suggest that Coates may have had contacts with the artistic community before emigrating.

Coates's Canadian residency ended in 1916 when he, like many other first generation English-Canadians, enlisted in the Canadian Expeditionary Forces. On 5 August 1916, age 25, the 5'6" Frederick Coates enlisted in the Canadian Army Medical Corps (Coates Attestation Papers, 1916, Library and Archives of Canada digitized records). The date of his enlistment is significantly later than many of Coates's fellow English-born Canadians, who were amongst the first tranche to sign up for military service. Two details in his attestation papers suggest a reason for this late enlistment, the first being his stated occupation as 'sculptor', and the second, his religious beliefs as a 'Quaker'.

Inscriptions in his field notebooks indicate that Coates was at Whitley Camp, Surrey in 1917 with the $66^{\text {th }}$ Canadian Field Artillery (CFA), and his discharge papers note that he served in France with the medical corps. Photographic evidence and notations in his notebooks or on photographs indicate that Coates was 'with the guns' (Coates fonds, no reference available on the photograph). Other evidence includes a ticket stub from the Cinéma Américain, souvenir postcards from the Somme and other French and Belgian locales, as well as ephemera suggesting that Coates was at Liège in 1917, and again in France in late 1918. Photographs of Coates either close to, or at the front, as well as alongside troop trains (which he painted with cartoons and graffiti), indicate that he enjoyed the esprit de corps and, given his religious affiliations, may have served as either an orderly or a stretcher bearer in the early months of his overseas experience. This posting was not unusual for artists: the British sculptor Francis Derwent Wood occupied a similar position at the $3^{\text {rd }}$ London General Hospital before he had the idea of using his talent to create facial masks for disfigured servicemen in what came to be known as the 'Tin Noses Shop' (Muir, 1918), while the painter W.H.R. Nevinson worked as an orderly in the 
notorious 'Shambles', the Dunkirk sheds, before redeploying as a war artist (Walsh, 2002: 98).

Coates's service in hospitals further away from the frontline is better documented.

Postcards, photographs and his extensive collection of field notebooks, consisting mainly of sketches, constitute Coates's de facto war journal. He was first posted at the Westcliffe Eye and Ear Hospital in Folkestone, then at the Ontario Military Hospital at Orpington, and finally at The Queen's Hospital in Sidcup, Kent. All three hospitals had a specialized team looking after facially wounded soldiers: Canadian servicemen requiring 'aural and facial surgery' were initially sent to the Westcliffe (or West Cliff) Canadian Eye and Ear Hospital (Westcliffe War Diary, April 1917: 2). A special unit was set up there by University of Toronto medicine and dentistry graduate Lieutenant Carl William Waldron (1887-1977) and 'soon he had all the available beds there filled with facial casualties' (Carleen, 1977: 317-18).

The project to further develop the specialty at Westcliffe however came to an abrupt end, as recorded in the hospital's war diary entry for 18 May 1917:

The Department of Facial Surgery Cases which was first commenced in this hospital was by orders of the D.M.D. removed to the Ontario Military Hospital, Orpington. The Officers and Dental services connected with this were also transferred. The Officer Commanding regrets very much that this work which was proceeding so satisfactorily had to be removed but this was necessitated by the fact that the extensions asked for could not be granted and the work of the hospital for which it was originally designed was being interfered with. (Westcliffe Eye and Ear Hospital War Diary, May 1917: 4)

According to the Orpington Hospital Diary, in May 1917 'two complete Wards were set aside for Jaw \& Face Cases, comprising over one hundred cases. A Number of Patients were transferred to these Wards from Westcliffe Eye \& Ear Hospital, Folkstone' (Orpington War Diary, 1917: 4). Coates is likely to have been amongst the staff transferred to Orpington, where he would further develop his medical knowledge and his artistic practice. The Ontario Military Hospital (No. 16 General Canadian Hospital), which opened in 1916 in Orpington, numbered up to two thousand beds (No. 16 Canadian General Hospital War Diary, August 1916: 4). Soldiers from across the Empire were admitted, but the staff, under the headship of Thomas McCrae, brother of In Flanders Field author John McCrae, were Canadian. Waldron sent for fellow Canadian Fulton Risdon when overwhelmed by his caseload and both, having been promoted to the rank of Captains, reported for duty at Orpington on 23 May 1917 (16 Canadian General Hospital War Diary, May 1917: 3). Coates thus worked with two of the most famous Canadian plastic surgeons; Waldron's signature on Coates's leave pass indeed shows that Waldron was one of Coates's superior officers (Coates fonds, no reference available).

It is also at Orpington that Coates's artistic practice gained momentum. In October 1917 the portraitist sculptor Frederick Lessore (1879-1951), son of the French watercolorist Jules Lessore, was taken on strength to supervise a team making 'wax and plaster models, coloured, drawings, and coloured photographs of wounds and war deformities' (Anon, 1918: 331). Lessore, whose name is often misspelt 'Le Sueur', was a generation older than Coates and already had an extensive portfolio of public portrait commissions in Britain and Canada, including one for King Edward (Lessore Exhibition Catalogue, 1913: 5). At Orpington, Lessore's wax models of injured faces raised significant interest in the Canadian medical press:

In the case of facial injuries, however, certain elements that do not have to be 
considered in general surgery call for more perfect and elaborate illustration. In a facial defect there is not only the functional question to consider, but also and above all, the plastic question, or question of appearance, which necessitates the adoption of a means of expression which can adequately render the exact appearance of the human face. There are, therefore, not only the surface contours of the features and their relation to one another, but such elements as the transparency of the skin, the colour, texture and opacity of the wounds and scarred tissue, the differentiation between clean and hairy skin, and between normal skin and the surface left by a healed wound that have to be taken into account and reproduced, if one is to give an exact representation of the condition of a patient before and after his operation.

(Anon., 1919: 947)

The description of the accuracy and realism of Lessore's work at the level of skin transparency adds another dimension to what is known of the use of plaster casts and drawings in the restoration of faces. This article stands out from other wartime and post-war publications in that it overwhelmingly asserts the precedence of the restoration of functions over that of appearance. The Orpington laboratory, or artist's studio, where Lessore and Coates worked together remained in operation even after most of the Canadian facial cases had been transferred to The Queen's Hospital, Sidcup, some five miles away. Lessore only officially ceased to be attached to Orpington in May 1919 (16 Canadian War Hospital War Diary, May 1919: 1). Close links remained between hospitals and the allied professions, first at Wimereux, France, the Cambridge Military Hospital in Aldershot, Orpington, Sidcup, and others, including the Croydon Jaw Hospital which began specializing in 1915 (Hussey, 2014: 598). The Orpington Hospital war diary shows that patients and staff - including Coates - regularly transferred to Sidcup for treatment or training purposes (No. 16 Canadian Hospital War Diary, January 1918: 3).

When Coates arrived at The Queen's Hospital, he had therefore already worked closely with facially disfigured patients, and with fellow artists such as his Toronto colleague Walter Duff. A professional engraver, watercolorist and ceramicist, Duff ran one of the prosthetic studios at Orpington alongside Lessore. A bas-relief photograph of a portrait of Duff, and another of Duff applying plaster to a patient at Orpington are in the Coates fonds, as well as a post-war photograph of Duff in a cowboy costume at one of Coates's masquerade parties. Coates and Duff thus shared a common artistic practice, but they also enjoyed a personal friendship.

A contemporary report by 'A Lady Visitor' to Orpington mentions Lessore and Duff working together and acknowledges that many patients were 'marvelously restored from their original disfigurement' (quoted in Pateman, 2012: 29). The visitor describes Duff's studio as full of 'paintings of wounds, and facial cases in various stages' and praises 'his clever invention of painted fingers, and spectacles having the eye painted on them with copper attachments when there is no socket for an artificial eye to be inserted' before informing her readers that 'Both these talented officers can show you other work, exquisite statuettes and charming painting'.

The emphasis on the successful restoration illustrates the propagandistic tendency of writers to describe the artists' work as products of redemption. The author, however, quickly diverts the gaze from the broken faces, towards the artists' 'exquisite statuettes and charming paintings', that is, onto the comfortable notion of artists performing aesthetic rather than rehabilitative acts. This signals a key critique of the work of the prosthetic studios versus the surgical suite. As Katherine Feo writes: 'though the masks were intended to ensure that disfigurement would not render wounded men economically dependent on the state, their production also signals the implicit belief that a measure of hiding or covering was necessary to 
ameliorate the shattering effects of war that was reflected in the faces of the mutilated veterans' (Feo, 2007: 17). This sets up an imperative to examine Coates's practice in the surgical suite, above that of the prostheticists and epithesists. As Feo notes, Anna Ladd made between one and two hundred masks for disfigured soldiers, a figure that seems insignificant in a war of mass casualty. The role of the artist in the surgical suite - more than 6,000 combatants were treated at Sidcup alone (The Queen's Hospital, 1917-1921 report, 1921: 2) - is potentially more significant to the historical and medical record.

Coates's journey through different hospitals exemplifies the frequent movement between the hospitals of staff and patients from many nations as well as the growing awareness that facial cases needed adaptive, multiple, and creative treatments. The dental surgeon William Kesley Fry writes in 1917 of his collaboration with Gillies: 'The reconnaissance into the other man's territory has led to the closest cooperation between us working as a team and we believe with satisfactory results' (Hussey, 2014; 599). Correspondingly, an editorial in The Canada Lancet of July 1918 describes the new field of plastic surgery and explains the close relationship between surgeons and sculptors:

As the sculptor carves in stone and wood, so the modern surgeons carve in flesh and bone that the loved features may be restored to soldiers who have been wounded in battle [...] We give him back his old features. This is a new branch of surgery that is developing very fast. When a soldier is wounded in the face we try to get a photograph of him, as he was when he left his home. The photograph is given to a sculptor, who makes in clay and plaster a model of the man's features as his family knew them, and this model is then passed to the surgeons and dentists who have the work of translating into flesh and bone the cold work of the sculptor. Flesh, bone and cartilage is taken from different parts of his body, because we find these tissues grow best when from the same man, and the surgeons make jaws, noses and cheeks, and end by giving the man back the face which he had when he went to the war (Canada Lancet, July 1918: 491).

The approach adopted by Lessore's team of allied artist workers explained here, while a more technical report than that of the 'Lady Visitor', is notable for its corresponding optimistic claim that the surgeons were able to fully restore their patients' pre-wound appearances.

Teams were working in parallel in different structures, but efforts were also made to gather the patients and the teams as opportunities and necessities for specialization presented: 'in war the surgeons were able to concentrate many cases of a similar kind in one hospital and pursue the study of the work together' (Anon., Canadian Medical Association Journal, 1919: 947). The creation of The Queen's Hospital was the climax of this process of centralization that in time would bring together the majority of facially injured soldiers from Britain and the Empire, and those involved in their treatment. But as shown in this article, the work of sculptors had already become entrenched in hospital protocol beforehand. The following was noted by Alexander Primrose, the consulting surgeon to the Canadian Forces in England:

At our solicitation money was provided by the Dominion Government and at Orpington we secured the services of a group of experts consisting of an excellent sculptor, who reproduces very beautiful models in wax illustrating the various stages of such wounds as those of the face and jaws, from the condition at the time the wound was inflicted up to the final processes of repair [...] Then we have an expert who makes plaster casts, another 
who is an artist in making coloured pictures in pastels, yet another who specializes in coloured photography, transparencies and in the production of cinematograph films (Primrose, 1918: 26).

This description of the surgeons' needs for complex plaster models underlines the significance of the role of artists, with the use of the aesthetic descriptor 'beautiful' to describe the 'models in wax', pointing to the exceptionally high level of artistic skill at work in the difficult process of facial 'repair'. What is important to note is that even after the majority of cases relocated to Sidcup, Lessore's laboratory remained at Orpington, 'but its staff was made mobile and able to follow the work in all other hospitals' (Canadian Medical Association Journal, 1919: 947). Coates's own journey, traceable through his field notebooks and postcard collections, exemplifies this movement from the front to far behind the lines, as well as the collaboration between surgeons and artists that started well before The Queen's Hospital was established.

\section{Rebuilding men: Coates's work and life in the 'sister' hospitals for facially injured combatants at Westcliffe, Orpington, and Sidcup}

The purpose-built Queen's Hospital opened on the land of the Frognal estate in Sidcup, Kent, in July 1917, thanks mainly to the efforts of surgeon Harold Gillies (1882-1960). Separate wings were devoted to the facially wounded from Great Britain and the Dominions whilst Gillies, himself from New Zealand, oversaw the work. The Queen's Hospital - later renamed Queen Mary's Hospital in honour of one of its most illustrious patrons - offered specialized care for facially wounded soldiers and sailors from 1917 until 1925, when the last few remaining cases were transferred to Roehampton. An official report on the work carried out between July 1917 and June 1921 reveals that the institution had admitted over 6,000 patients, including 505 wounded Canadians amongst whom were thirty officers and 475 other ranks (The Queen's Hospital, 1917-1921 report, 1921: 2). The Canadian unit remained in activity until the end of the war, when patients and staff returned to Canada. In May 1919, Canadian servicemen who still required treatment were sent to Sainte Anne's Hospital, Sainte-Anne-de-Bellevue, Quebec, an institution built in 1917 for the care of ex-servicemen and one at which Coates served for a short period of time before returning home to Toronto (Makovsky, 1997: 19). The maxillofacial unit was subsequently moved to Christie Street Hospital, Toronto, which was also devoted to war veterans, especially orthopedic cases (Carleen, 1977: 318). Dentists and surgeons joined forces to help the wounded Canadians, of whom 'Over two thousand cases passed through this service [the Canadian service of facial injuries] overseas, and about five hundred since returning to Canada' (MacPhail, 1925: 397).

If the number of British soldiers who sustained facial injuries far exceeded that of their Canadian comrades, the ingenuity of Canadian surgeons in the treatment of this kind of wounds was noted. The Canadians, as Pinkerton observes, were well placed to transfer North American medical knowledge to war surgery, despite initial British resistance (Pinkerton, 2008: 77-86). At Sidcup, Risdon and Waldron made a significant contribution to the development of maxillofacial surgery. In his 1920 treatise Plastic Surgery of the Face, Gillies gives ample credit to his Canadian colleagues for the development and improvement of certain procedures: if Risdon's participation is acknowledged in passing, Waldron, Gillies reports, successfully adapted the Esser skin inlay (Gillies, 1920: 333). Although the work of the Canadian section is described as distinct from that of the British sections led by Gillies, mentions of exchanges of opinions, and on 
occasion of patients, can be found, probably for the purpose of sharing and perfecting techniques. The fluidity of staff and knowledge transfer between nationals should not be understated. The role of the Canadians in blood transfusion, for example, illustrates the exchange of knowledge between the British, Canadians, and latterly the Americans (Pinkerton, 2008: 77-86).

Risdon and Waldron have come to be known as being two of the fathers of North American plastic surgery, but their talent and interest were fuelled by their collaboration with other maxillofacial specialists - Waldron with Valadier in France, at Aldershot with Gillies, at Orpington with Risdon, and latterly with Gillies and Risdon again at Sidcup in 1917-1919 (Martin, 1986: 164). The atmosphere of 'friendly rivalry and friendly competition' between surgeons (Gillies, 1920: $\mathrm{x}$ ) was conducive to innovations. This collaboration was inclusive of surgeons, dentists and artists, the latter having, according to Suzannah Biernoff, a power that escaped the surgeon's: the ability to 'humanise' the patient (Biernoff, 2011: 677). The documents kept by Coates recording this period offer another insight into the interdisciplinary and international cooperation that took place at these hospitals during the war. The presence of artists amongst the hospital staff was not unusual and their works, such as Tonks's well-known pastels, offered a different view of the condition of the wounded from the thousands of black-and-white photographs representing the injured men at different stages in their treatment. Tonks is credited by Gillies with 'The foundation of the graphic method of recording these cases' (Gillies, 1920: $\mathrm{x}$ $\mathrm{xi}$ ). The drawings and pastels are presented as visual records complementing the written notes of the surgeon, but one might argue that the use of pastels versus oil or watercolours, aestheticizes these portraits, thus taking them from the realm of medical portraiture and into that of spectacle and voyeurism (Chambers, 2009: 588). As Emma Chambers comments, 'Tonks' portraits continually negotiate an uncomfortable ambiguity between the portrayal of the sitter as "object" (a record of a medical procedure), and as "subject" (an individual whose subjectivity is presented through portraiture) (Chambers, 2008: 604). Suzannah Biernoff highlights the 'fragility and mutability of the subject' of Tonks's portraits and goes as far as calling the pastels 'anti-portraits' (Biernoff, 2010: 39). These representations, she underlines, point not to the sitter but to the surgeon whose regenerative work is documented in the portraits. It is in this context of collaboration between artists and surgeons, art and medical science, and ethical considerations, that Coates fully developed his art.

\section{[Insert Figure 1]}

Figure 1: Coates outside a hospital hut.

This photograph of Coates standing outside a hospital hut shows him holding a sketchbook, an indispensable piece of equipment for any artist. More surprisingly, Coates is not wearing plain clothes or a uniform as in several other photographs kept in his fonds, but a white coat and white surgical cap, identical to those worn by surgeons in the operating theatre (Coates fonds, B750015/018P (37), (02)). Although the photograph was taken outdoors, Coates's clothes and his look of intense concentration suggest that he has just come out of the theatre, where he was working alongside doctors and nurses. Other pictures in the archives depict the inside of the theatre and are further evidence of Coates's presence and participation in the operations. His firsthand experience of the workings of the operating theatre informed his practice, which went beyond the traditional documentary and pedagogical purposes of medical illustrations (Thornton and Reeves, 1983: xiii). Whilst better-known sculptors such as Francis Derwent Wood declared that in their work 'no attempt is made for the alleviation of the sufferings of the wounded, to 
restore functioning or to produce a cosmetic effect by plastic methods' (Wood, 1917: 949), Coates's practice contributed to the repair of damaged faces. Photographs in Coates's archives show a series of his plaster casts of faces and limbs that played a key part in the preparation and execution of surgical reconstruction:

\section{[Insert Figure 2]}

Figure 2: Coates demonstrating the making of a cast

This photograph of Coates at work is reminiscent of other images showing sculptor Francis Derwent Wood's assistants carrying out a similar task (for example in photographs of the 'Tin Noses Shop' by Horace Nicholls), but whilst the casts were used by Wood to create facial masks and attachments, Coates's casts contributed to the surgical reconstruction of the wounded face. The process of making plaster models is further described in a 1934 article, which underlines the importance of photographs in Coates's work: 'In conjunction with the British Medical Corps he studied photographs of patients before and after they had been wounded, and constructed plaster models to scale' (Toronto Star Weekly, 1934). Here again, the sculptor's work required him to work in close collaboration with another artist, the photographer. The article further emphasizes the usefulness of Coates's artifacts to the medical practitioners:

The plastic surgeons followed these forms minutely as they twisted human flesh into new noses and jaws. Dozens of operations were often required on one man, and all the time Frederick Coates acted as the 'facial architect'. The doctors knew how to graft flesh and bones; Coates knew what a remodeled face should look like. It was a sordid business at best, though, and he was glad to return to Toronto in 1920 (Toronto Star Weekly, 18 August 1934 [in Coates fonds]).

Working with plaster casts of the injured faces, surgeons could plan the reconstruction of their patients' facial features in three dimensions thanks to the indications provided by Coates. Unlike medical sketches, the three-dimensional artefacts made by Coates had a tactile dimension that was particularly useful to the surgeons for whom touch was of key importance. Gillies, for example, would resort to 'manual palpation to determine the extent and type of tissue lost' when examining his patients (Biernoff, 2010: 41).

\section{[Insert Figure 3]}

Figure 3: Plaster casts

The three-dimensional casts made by Coates gave the surgeon an accurate idea of the amount of flesh needed to repair cheeks, noses and foreheads, in a way that photographs, sketches and drawings could not. The lines drawn on some of the casts are further evidence of the use of these casts in preparing for surgery, and the captions summarising the procedure that can be seen on a few casts suggest that they were used to document and teach these techniques, perhaps to visitors to the Queen's Hospital's medical museum where this display case might have been found.

The casts testify not only to the usefulness of three-dimensional representations in the surgical process, but also to the collaboration between sculptors and surgeons and beyond, to the artistic quality of these artefacts. Indeed, Coates's attention to detail is illustrated in his modelling 
of delicate eyelashes, eyebrows, moustaches and wrinkles of individual patients. The sculptor's aesthetic is thus artistic and architectural, concerned with detailed surface appearance, and the structural underpinning of the entire 'edifice' of the face. Coates, it must be remembered, trained in architecture and devoted much of his post-war life to teaching house-modelling, and theatrical design. The link between First World War medical practice and architecture is identifiable elsewhere in a series of photographs by official photographer Horace Nicholls representing a destroyed building and a soldier's disfigured face, both of which participate in telling a story of reconstruction in wartime Great Britain (Biernoff and Tynan, 2012). Coates, if he was not the 'chief builder' in the sense in which the term 'architect' was originally used, was nevertheless a key contributor in the process of re-building of facial features through modern plastic surgery methods. The fruitfulness of such collaborations between sculptors and surgeons is underlined by $21^{\text {st }}$-century sculptor Luke Shepherd, who uses clay modelling to help maxillofacial surgeons develop a better understanding of form (Shepherd, 2005).

If Coates's practice was intimately linked with what was happening in the operating theatre, he also worked in a dedicated workshop set up at the hospital.

\section{[Insert Figure 4]}

Figure 4: Coates in his workshop

This photograph, according to a handwritten note on the verso, was taken inside the artist's studio in 1920, after Coates's return to Canada. A close examination of it and other photographs taken in his studio give us a greater understanding of the artists' methodology, and the breadth of their roles in facial reconstruction that took place at the Queen's Hospital and the sister hospitals during and immediately after the war (Coates fonds, B75-0015/018P (44)). In this photograph Coates is not posing, rather, he is absorbed in the making of a small piece, probably a facial attachment with glasses. On a workbench near him is a white plaster cast or mask of a whole face, and another facial cast above it hanging on the wall. The painstaking work Coates is conducting contrasts with what appear to be bulky welding torches, metal stamping machinery and other heavy tools near him. The dress of two of his female co-workers suggests that, unlike Coates who is out of uniform and a civilian by 1920, they are attached to the hospital in a professional capacity as nurses. They, too, are busy sketching and painting, unlike their sister colleagues working with patients in the wards. One of the nurses has a set of watercolours by her side which suggests that she may also be responsible for the portraits of patients on the wall, that while they resemble those of Tonks, in fact have much harder lines, and less impressionistic colouring which resembles paint rather than pastel. The other nurse is using pen and ink. The identities of these two young women are unknown, but the presence of women in the artist's studio tells another facet of the collaborative work that occurred in the war time hospital environment between men and women, just as the role of women surgeons in reconstructive surgery is also being rediscovered (Murray, 1920: 162). One other documented example of a woman artist is that of Kathleen Scott, wife of the Antarctic explorer, who sculpted for the benefit of Sidcup patients (Young, 1995).

The manner in which visual representations of patients are lined up on the wall of Coates's studio differs significantly from the artistically displayed plaster casts visible on photographs of Ladd's or Wood's studios (examples can be found in the Imperial War Museum and the Smithsonian Museum collections). This suggests that the studio was not open to the public or to the patients 
themselves. This photograph provides further evidence that Coates was working as part of a team of artists, each with his or her own speciality - drawing, painting or sculpting. The complexity of maxillofacial surgery called for a team of medical and artistic practitioners working together.

Furthermore, the photograph demonstrates the role of women practitioners in the surgical process and suggests a rich field of research that remains to be explored, including the work of Canadian artists Anne Savage and Dorothy Cole, who accompanied Waldron 'to the Christie Street hospital in Toronto, and then to Minneapolis, where they spent their afternoons making drawings of facial reconstructions' (Meadowcroft, n.d. n.p.). Savage, Cole, and Waldron's collaboration and subsequent relocation reinforces the idea that the reconstruction teams continued to be close-knit after the war.

Coates's practice was not restricted to providing surgical models and recording procedures. His archives reveal that he also made epitheses and prosthetic attachments for soldiers whose faces could not be satisfactorily repaired. In particular, a series of four photographs found in his archives illustrates the eyeglass and false eye that he constructed for a soldier with a hollow eye socket. This type of reconstruction was considered a last resort solution as MacPhail underlines:

The most piteous aspect in the medical service was not the dead and those about to die, but the living whose facial wounds obscured their resemblance to humanity. Much was done to ease their pain and restore their appearance; but at best, after observing the cases or looking at photographs, paintings, and casts, and yielding full admiration to the triumph of surgical dexterity, one looks with pity upon the sorry spectacle. [...] All the resources of surgeons, dentists, and artists were lavished upon them; yet the much that was done was less apparent than the little that could be done (MacPhail, 1925: 116).

The pessimistic view, the 'pity' and 'sorry spectacle', of the disfigured men's final condition contrasts with the praise of the progress accomplished in the field of plastic surgery, discussed previously. The observation that not all men could see their appearance restored inspired sculptors like Coates, Ladd and Wood to make 'tin faces', masks that would cover part or all of the damaged face. But these were heavy, uncomfortable and required regular adjustments. In addition, they failed to convey any emotions but the one painted on them initially. Smaller attachments, like the one Coates is shown working on in Figure 3, were considered to be more practical, in cases in which the disfigurement was limited to a specific area. Coates also made larger pieces, such as artificial limbs that can be seen in other photographs held in the Coates fonds (B75-0015/010P). But Coates's mastery of facial features, even before he joined the team at Sidcup, made him a particularly talented facial architect. In turn, his artistic practice underwent significant changes during the war, as shown in the evolution of his technique visible in the sketches featured in his field books. As with the surgeons, the artists' exposure to unprecedented numbers of wounded led to significant technical improvement.

When not drawing anatomical studies, or his fellow soldiers at rest, Coates, an accomplished violinist, filled his notebooks with sketches and watercolours of concert parties, dogs, landscapes, war memorial designs (he would later be commissioned for these), theatrical performances and costumes, clearly beginning what would be a mainstay of his post-war work, theatrical costumes and stage design. The experience he gained sculpting faces and bodies during the war found its natural expression in his later work as a theatre production sculptor, with an interest in masks.

In addition to his surgery-related wartime art practice, Coates illustrated cartoons for The 
Strafer, a trench journal produced by the $66^{\text {th }}$ Battery and intended for servicemen but also their families in Canada (Anon., 1919: 32; Seal, 2013:15). Photographs in the Coates fonds show his extensive graffiti and cartooning done in either white paint or chalk along the length of a railway carriage transporting soldiers towards the Front. Coates's field books, photographs and postcard collections - many of which have been removed from scrapbooks and thus have few identifiers provide the opportunity to follow his fascinating journey. In particular, his Sidcup and Orpington field books provide a non-linear narrative of an artist serving in the war and give evidence of an adaptive, creative and dedicated mind.

\section{Conclusion}

Coates was honourably discharged for non-medical reasons in May 1919 and after a trip to Nottingham, he returned to Toronto. Letters applying for jobs and rejection letters in Coates's archives suggest that the artist's transition to civilian life was as uneasy as that of many of his combatant brothers and nursing sisters. Coates returned to the Royal College of Dental Surgeons, and in 1921 he was put in charge of the modeling studio (Averill et al., 2014: 61).

A series of photographs in Coates's archives record the 1922 construction of Sherwood, Coates's home located on the outer edges of Toronto, in what would become known as the eccentric colony 'Oddity's End'. The Sherwood guestbook indicates a lively social community of artists, actors and theatre directors, but four photographs are especially intriguing in the context of Coates's war work. Three photographs depict a trio of workers participating in the digging of a foundation trench for the house. Another shows Coates with his arms around two of the workers. All three workers are facially disfigured, clearly from wounds either to the mouth, the nose, or the jaw, suggesting that Coates remained acquaintances, if not close friends, with some of his former military patients four years after the war. The bonds that were born during those long months in the maxillofacial wards did therefore not disappear once the men had left and remained not only amongst patients, but also between patients and staff.

Coates's post-war life saw him pursue his successful and diverse artistic practice, at one point experimenting with music and light as an artistic medium. But where the artistic movement of continental contemporaries Otto Dix, George Grosz or Heinrich Hoerle, 'employ[ed] the figure of the mutilated, disabled veteran as part of a wider commentary on a decadent, militaristic society' (Garner \& Stanton, 2007: 506), Coates's artistic practice illustrates a more restorative practice. His Arts and Crafts style home, photographs of medieval costume parties, romantic theatre designs and costumes, and extensive, realistic life studies signal an ethos contrary to the continental impulse of Dada, Surrealism, and Modernism, and perhaps, one towards self-healing, or forgetting. This proposes the subject of the artist's exposure to war-trauma as another avenue for future research.

This article aims to recover the work of artists who made significant, albeit little recognized, contributions to medical history through examining the artistic mastery that became a key feature of their military service and which helped restore not only the features but also the sense of identity, and indeed the lives of many (Delaporte, 1996). Coates's personal story is particularly intriguing, and worthwhile, not the least for his transition from the operating theatres of the Great War to the entertainment theatres of Toronto but also for the important allied health model it presents. The emphasis he put on sculpture as an integral part of the surgical process and the recognition he and his peers gained, although it has long been overlooked in First World War and medical studies, is being re-discovered through collaborations between sculptors and 
surgeons, a century later (Shepherd, 2005). This research highlights the need for a broader understanding of the role and international dimension of the work of First World War artists and surgeons, including women, as a way of re-facing the cultural legacies of the disfigured soldier, as well as an examination of the effect war had on the artists' individual and collective practices.

\section{Illustrations}

Figure 1: Coates in a white coat, outside a hospital hut, (C) University of Toronto Archives, Fred Coates Fonds B1975-0015/010P (37)

Figure 2: Coates demonstrating the making of a cast (C) University of Toronto Archives, Fred Coates Fonds B1975-0015/010P (19)

Figure 3: Coates in front of a cabinet containing casts (C) University of Toronto Archives, Fred Coates Fonds B1975-0015/010P (38)

Figure 4: Coates in his workshop (C) University of Toronto Archives, Fred Coates Fonds B19750015/010P (44)

\section{Works cited}

Anon. 1913. Exhibition of Sculpture by Frederick Lessore in the Galleries of the Art Association of Montreal, 15 October - 15 November, 1913. Montreal: The Art Association [Accessed 12 February 2015]. Available at <https://archive.org/stream/cihm_74018\#page/>.

Anon. Coates' Attestation Papers. 1916. Library and Archives Canada: Soldiers of the First World War: 1914-18 [Accessed 25 May 2015]. Available at <http://www.baclac.gc.ca/eng/discover/military-heritage/first-world-war/first-world-war-1914-1918cef/Pages/image.aspx?Image $=025626 \mathrm{a} \& U R L j p g=\mathrm{http} \% 3 \mathrm{a} \% 2 \mathrm{f} \% 2 \mathrm{fdata} 2$.archives.ca $\% 2 \mathrm{fcef} \% 2 \mathrm{fre}$ n2\%2f025626a.gif \&Ecopy=025626a> .

Anon. 16 March 1918. Medical News. The British Medical Journal, 1(2985): 330-31.

Anon. July 1918, Editorial, The Canada Lancet, 51(11): 491.

Anon. October 1919. Canadian National War Museum: Description of a Series of Wax Models Made by Major Lessore for the Canadian Government at the Canadian Hospital at Orpington, Kent'. Canadian Med Association Journal, 9(10): 947-48.

Anon. 1919. The Story of the Sixty-Sixth C.F.A. Edinburgh: Turnbull and Spears.

Anon. October 1919. Canadian National War Museum: Description of a Series of Wax Models Made by Major Lessore for the Canadian Government at the Canadian Hospital at Orpington, Kent. Canadian Medical Association Journal, 9(10): 947-48. 
Averill, H., Gamble, M., and MacDonald, L. 2014. We Will Do Our Share: the University of Toronto and the Great War. Exhibition by the University of Toronto Archives. Toronto:

University of Toronto Press.

Bamji, A. 2003. Facial Surgery: The Patient's Experience. In: H. Cecil and P. Liddle, eds, Facing Armageddon: The First World War Experience. London: Leo Cooper, 490-501.

Biernoff, S. 2010. Flesh Poems: Henry Tonks and the Art of Surgery. Visual Culture in Britain, 11(1): 25-47.

Biernoff, S. 2011. The Rhetoric of Disfigurement in First World War Britain. Social History of Medicine 24(3): 666-85.

Biernoff, S., and Tynan, J. 2012. Making and Remaking the Civilian Soldier: The World War I Photographs of Horace Nicholls. Journal of War and Culture Studies, 5(3), 277-93.

Carleen, K. 1977. Obituary: Carl William Waldron. Plastic and Reconstructive Surgery, 60(2): 317-19.

Chambers, E. 2009. Fragmented Identities. Art History, 32(3): 578-607.

Delaporte, S. 1996. Gueules Cassées: Les Blessés de la Face de la Grande Guerre. Paris: Noêsis.

Feo, K. 2007. Invisibility: Memories, Masks and Masculinities in the Great War, Journal of Design History, 20(1): 17-27.

Garner, J. \& Stanton, B. 2007. The Gas Heart: Disfigurement and the Dada Body. Modern Drama, 50(4): 500-16.

Helmers, M. 2010. 'Iconic images of wounded soldiers by Henry Tonks'. Journal of War \& Culture Studies, 3(2): 181-99.

Hussey, K.D. 2014. British Dental Surgery and the First World War; the treatment of facial and jaw injuries from the battlefield to the home front. British Dental Journal, 217(10): 597-600.

MacPhail, A. 1925. Official History of the Canadian Forces in the Great War, 1914-19. Ottawa: F. A. Acland.

Makovsky, P. 1996. The Stuff Dreams Are Made Of: The Art and Design of Frederick and Louise Coates (exhibition catalogue). Toronto: University of Toronto Library.

Martin, D. 1986. The Ontario Military Hospital, Orpington, England, 1916-1919. Families, 25(3): 164-68.

Meadowcroft, B. 'Anne Savage, A.R.C.A (1896-1971)'. Alan Klinghoff Gallery website [Accessed 5 November 2015]. Available at $<$ http://www.klinkhoff.ca/canadian-artist/AnneSavage $>$. 
Muir, W. 1918. The Happy Hospital. London: Simpkin, Marshall, Hamilton and Kent.

Murray, F. 1920. Women as Army Surgeons: Being the History of the Women's Hospital Corps in Paris, Wimereux, and Endell Street 1914-1919. London: Hodder and Stoughton.

Pateman, J. 2012. The Ontario Hospital. Sleaford: Paterman Press.

Pinkerton, P. H. 2001. Canada's transfusion medicine pioneer: Lawrence Bruce Robertson.

Transfusion, 41: 283-86.

Primrose, A. 1 October 1918. The Address of the President, Academy of Medicine, Toronto. The Canada Lancet, 52(2): 61.

Seal, G. 2013. The Soldiers Press: Trench Journals in the First World War. London: Palgrave.

Shepherd, L. 2005. Practical Sculptural Training for the Plastic Surgeon. International Journal of Surgery, 3: 93-97.

Taylor, A. 2014. Changed by War: An Artist at War. University of Toronto Magazine [accessed 5 November 2014]. Available at: <http://www.magazine.utoronto.ca/autumn-2014/changed-bywar-an-artist-at-war-alice-taylor/>.

Thornton, J. \& Reeves, C. 1983. Medical Book Illustration: A Short History. Cambridge:

Oleander.

Walsh, M. 2002. C.R.W. Nevinson: the Cult of Violence. Boston: Yale University Press.

Wood, F. D. 1917. Masks for Facial Wounds. The Lancet, 189(4895): 949-51.

Young, L. 1995. A Great Task of Happiness: The Life of Kathleen Scott. London: Macmillan. 